\title{
Trematode (Digenea: Bucephalidae) infection in the burrowing clam Tridacna crocea from the Great Barrier Reef
}

\author{
C. C. Shelley ${ }^{1}$, J. S. Glazebrook ${ }^{2}$, E. Turak ${ }^{1}$, L. Winsor ${ }^{1}$, G. R. W. Denton ${ }^{1}$ \\ ${ }^{1}$ Zoology Department, School of Biological Sciences, James Cook University, Townsville 4811, Queensland, Australia \\ ${ }^{2}$ Graduate School of Tropical Veterinary Science, James Cook University, Townsville 4811, Queensland, Australia
}

\begin{abstract}
Larval trematode (Family Bucephalidae) infection of Tridacna crocea (Lamarck 1819) was investigated to determine pathological effects on the host. Of $108 \mathrm{~T}$. crocea gonads examined, $13(12 \%)$ were found to be parasitised. The bucephalid caused castration in heavily infected clams, gonadal tissue being completely replaced by sporocysts. The parasite was also found in the kidney, digestive gland and ctenidia. This is the first record of a bucephalid trematode in a member of the Tridacnidae. The parasite is of potential importance to tridacnid shellfisheries currently being developed.
\end{abstract}

\section{INTRODUCTION}

The role of bucephalid trematodes as parasites of commercially important molluscs was summarised in a review by Cheng (1967). Parasitic castration of bivalves by bucephalid trematodes has been reported in several species including Abra alba (Johnston et al. 1982), Crassostrea virginica (Turner 1985), Pecten alba (Sanders 1966) and Proptera purpuratya (Flook \& Ubelaker 1972). Their occurrence has also been investigated in Anodonta piscinalis (Stadnichenko 1974), A. cygnea and $A$. anatina (Koubek 1977), Cardium edule (Deltreil \& His 1970, Matthews 1973), Crassostrea madrasensis (Mohan 1978), C. virginica (Cheng \& Burton 1965. Feng \& Canzonier 1970, Tripp 1973), C. gigas (Chun 1974), Lyonsia hyalina (Stunkard 1976), Ostrea lutaria (Millar 1963), Pectin alba (Sanders \& Lester 1981). Perna perna (Umiji et al. 1976), Unio pictoram (Stadnichenko 1974, Koubek 1977), and U. tumidus (Koubek 1977).

The present interest in the mariculture of tridacnid clams for restocking of reefs from which clams have been overcollected, and as a commercial venture (Munro \& Heslinga 1983), prompted an investigation of the bucephalid and its effects on its host. This article records a bucephalid infection in a species of the Tridacnidae Tridacna crocea (Lamarck 1819) for the first time, estimates its prevalence and describes associated pathological changes.

\section{MATERIAL AND METHODS}

All Tridacna crocea were collected from the littoral zone in Cattle Bay, Orpheus Island, Queensland, Australia $\left(18^{\circ} 37^{\prime} \mathrm{S}, 146^{\circ} 30^{\prime} \mathrm{E}\right)$ between June 1984 and January 1986. As $T$. crocea were already being collected for heavy metal analysis (Denton unpubl.) and growth validation trials by the senior author (C.C.S.), gonads collected from these clams formed the material for this study. The gonads of $108 \mathrm{~T}$. crocea were examined in this study. In a few individuals other organs and tissues (ctenidia, kidney, and digestive gland) were examined.

Identification of the parasite to family was confirmed by Dr D. Blair of Canterbury University, New Zealand (pers. comm.). Voucher specimens of the parasite have been lodged at the Queensland Museum, Brisbane, Australia (Nos. GL 4901-4904)

Tridacna crocea gonads were dissected from the visceral mass, and fixed in $10 \%$ formalin in seawater prior to storage in $70 \%$ alcohol. Tissue blocks, taken from the approximate centre of the gonad, were processed to paraffin wax, sectioned at $6 \mu \mathrm{m}$, and stained by haematoxylin and eosin (H\&E) (Winsor 1984). A preliminary examination of the material was undertaken using the light microscope to determine the presence or absence of parasites. Pathological changes associated with the infection were then described. Special stains utilised to aid in the assessment of infected material 


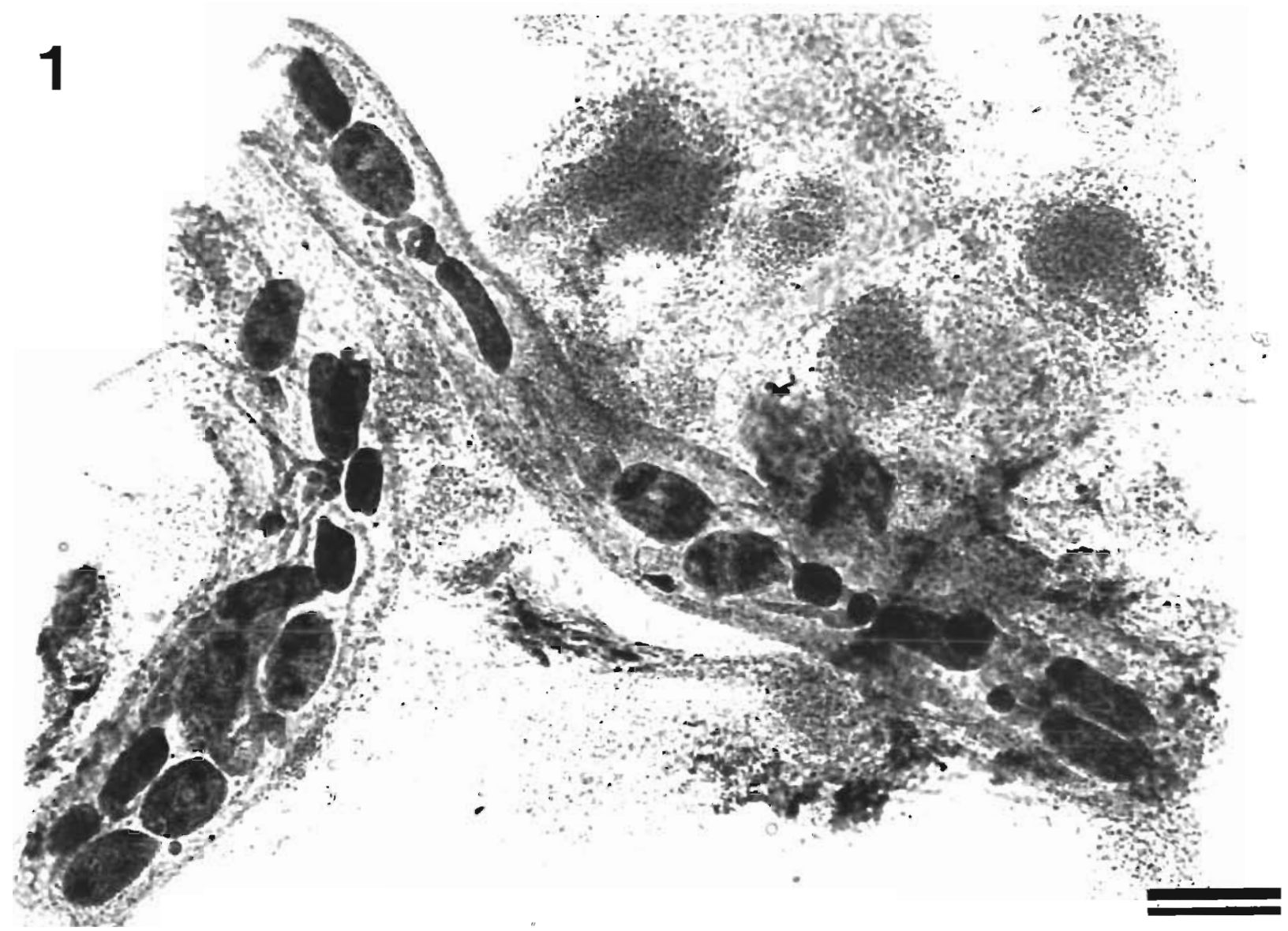

Fig. 1. Bucephalid sporocyst containing cercariae. Whole mount stained with Gower s Carmine; bar $=100 \mu \mathrm{m}$

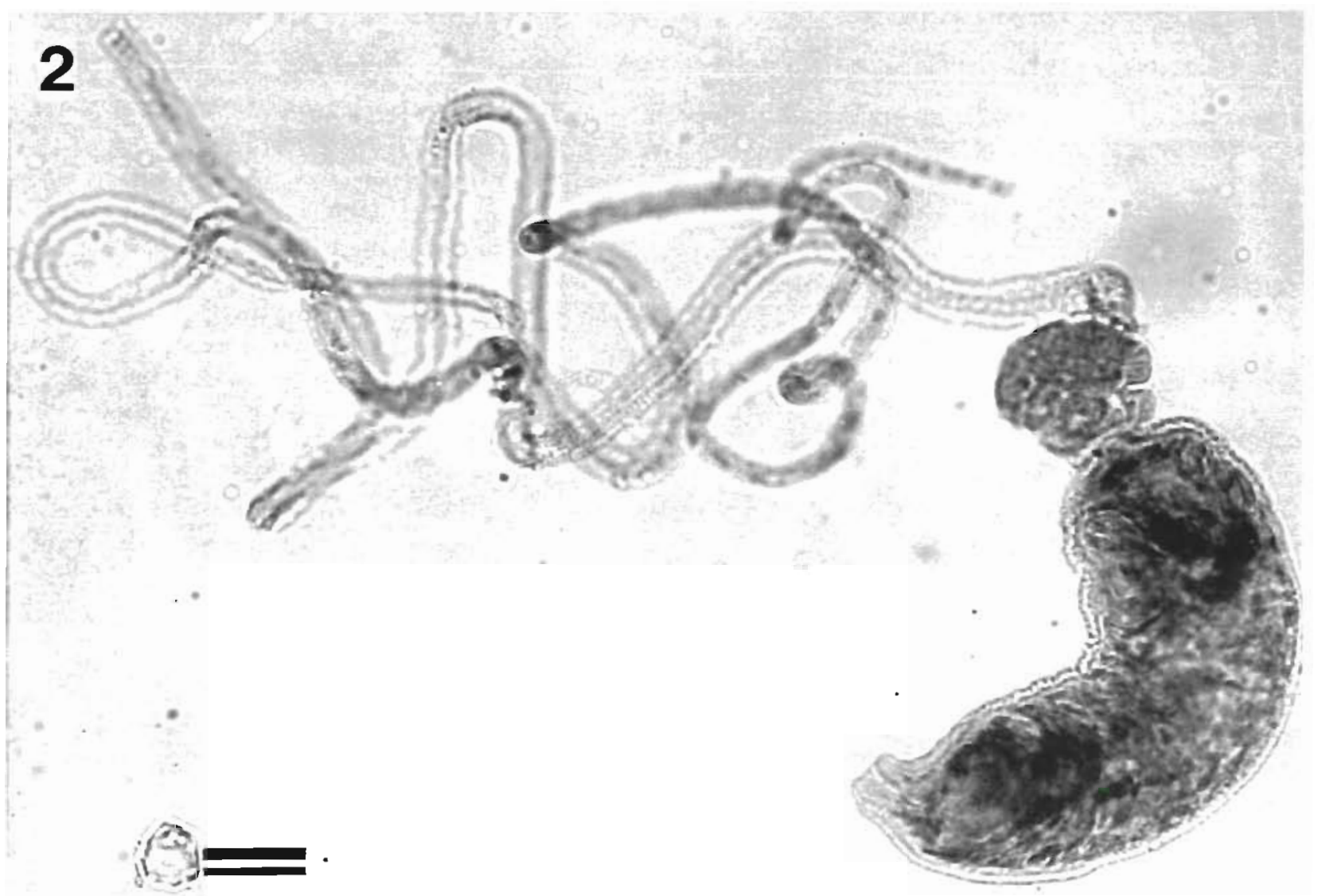

Fig. 2. Single cercaria, with spineous tegument, distinct furcal stem and furcae with paired excretory cells along their length. Stained with Gower's Carmine, bar $=100 \mu \mathrm{m}$ 
inluded Mallory-Heidenhain, Gomori's trichrome, and Martius scarlet blue.

Some parasites were teased from infected gonads, stained by Gower's Carmine and whole mounts prepared of sporocysts and cercariae.

\section{RESULTS}

\section{Description of sporocyst and cercaria}

In whole mounts of the trematode, sporocysts (Fig. 1) were approximately $0.2 \mathrm{~mm}$ in diameter. They contained germ balls and cercariae in various stages of development to mature cercariae with long furcae (Fig. 2). The most developmentally advanced cercariae averaged $0.2 \mathrm{~mm}$ in body length and $0.03 \mathrm{~mm}$ maximum body width and had well-developed (bi-lobed) furcae up to twice the length of the body, extending from distinct furcal stems. The cercariae were bounded by a spineous tegument. The anterior end of some of the cercariae appeared to be separated by a distinct collar.

\section{Prevalence of infection}

Of the 108 Tridacnea crocea gonads examined, 13 $(12 \%)$ were infected by the trematode. The parasite was also found in the digestive gland, ctenidia, kidney and haemal spaces of 2 individuals. There was little difference in prevalence rate between clams used in heavy metal uptake trials at Orpheus Island (14.2\%) and Townsville harbour (12\%)

\section{Pathology}

There were no gross differences between parasitised and non-parasitised clams except that sections through the gonad of heavily infected clams revealed homogeneous material (masses of sporocysts), whilst a mottled, heterogeneous appearance indicated a healthy gonad with male follicles being a slightly darker coloured cream than female follicles.

The level of infection of gonads by the parasite ranged from light to heavy. In light infections only a few gonadal follicles were affected, the remaining gonad appearing normal. In heavy infections most of the gonad had been replaced by sporocysts (Fig. 3), the typical hermaphrodite structure (Fig. 4) of the gonad often being unrecognisable. Other features of a heavily infected gonad included thickening of the muscular wall, a moderate infiltrate of leucocytes in interstitial areas, areas of fragmented and degenerative connective tissue, and a breakdown of normal gonadal architecture. Residual gonadal material in heavily infected clams seemed to be predominantly of one sex, suggesting preferential infection of the follicles of one sex (male or female) prior to infection of the other The last areas of gonad to become infected appeared to be the periphery and central areas adjacent to the digestive gland. Heavily infected gonads were hypertrophied.

In the ctenidia the parasite displaced portions of lamella, with the sporocyst occupying the interstitial connective tissue. As in the gonad, there was little host response. The ctenidia examined were only lightly infected. Some haemal spaces in the ctenidia were packed with sporocysts.

\section{DISCUSSION}

Although the prevalence of larval bucephalids in the population of Tridacna crocea studied was low (12\%), its effect on the reproductive capacity of those parasitised was significant, with complete castration seen in 4 clams, whilst 6 clams had between 50 and $75 \%$ of the cross-sectional area of their gonad replaced by the parasite. As the infection rate of bivalves by larval trematodes has been shown to differ between geographical location (Pekkarinen 1984), T. crocea populations elswhere may have a higher prevalence of infection. Bucephalid infestations have been reported to reduce resistance to stress in Cardium edule (Bowers 1969, Deltreil \& His 1970) and produce a decline in condition in both Pinctada martensii and Pecten alba (Sakaguchi 1964, 1965, Sanders \& Lester 1981); therefore a high prevalence may have implications for both wild and commercially cultured $T$. crocea. Prevalences of over $50 \%$ for larval trematodes in molluscs are not uncommon (Lauckner 1986). The prevalence rate $(12 \%)$ recorded from examination of gonads alone may be a conservative figure as other organs in clams with uninfected gonads may have been infected.

Because organs other than the gonad were examined in only a few individuals, any comments on the pattern and progression of infection would be highly speculative. Within gonads from heavily parasitised individuals, the apparent preferential destruction of the follicles of one sex of the hermaphroditic gonad suggests the sporocysts' direction of growth may be controlled by micro-environmental cues. The hypertrophied appearance of a trematode-parasitised gonad in this study may be similar to that described as 'under pressure' in Goniobus virginica by Huffman (1985). The breakdown of the follicular structure of an hermaphroditic gonad has been previously reviewed by Lauckner (1983).

Although Tridacna crocea is not being grown commercially, wild stocks are collected throughout the 


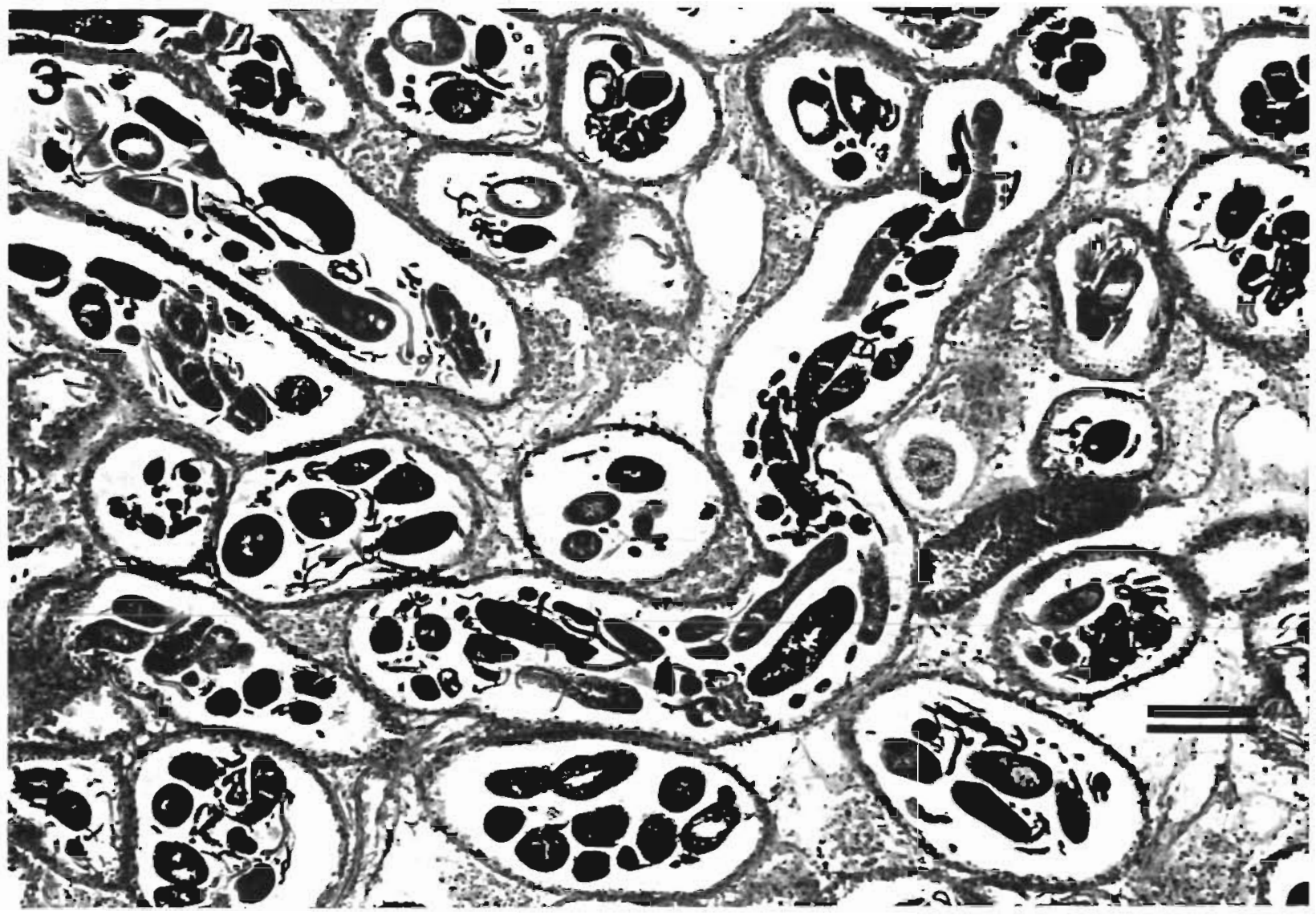

Fig. 3. Tridacna crocea. Parasitised gonad. Gonadal material has been replaced by branching bucephalid sporocysts containing

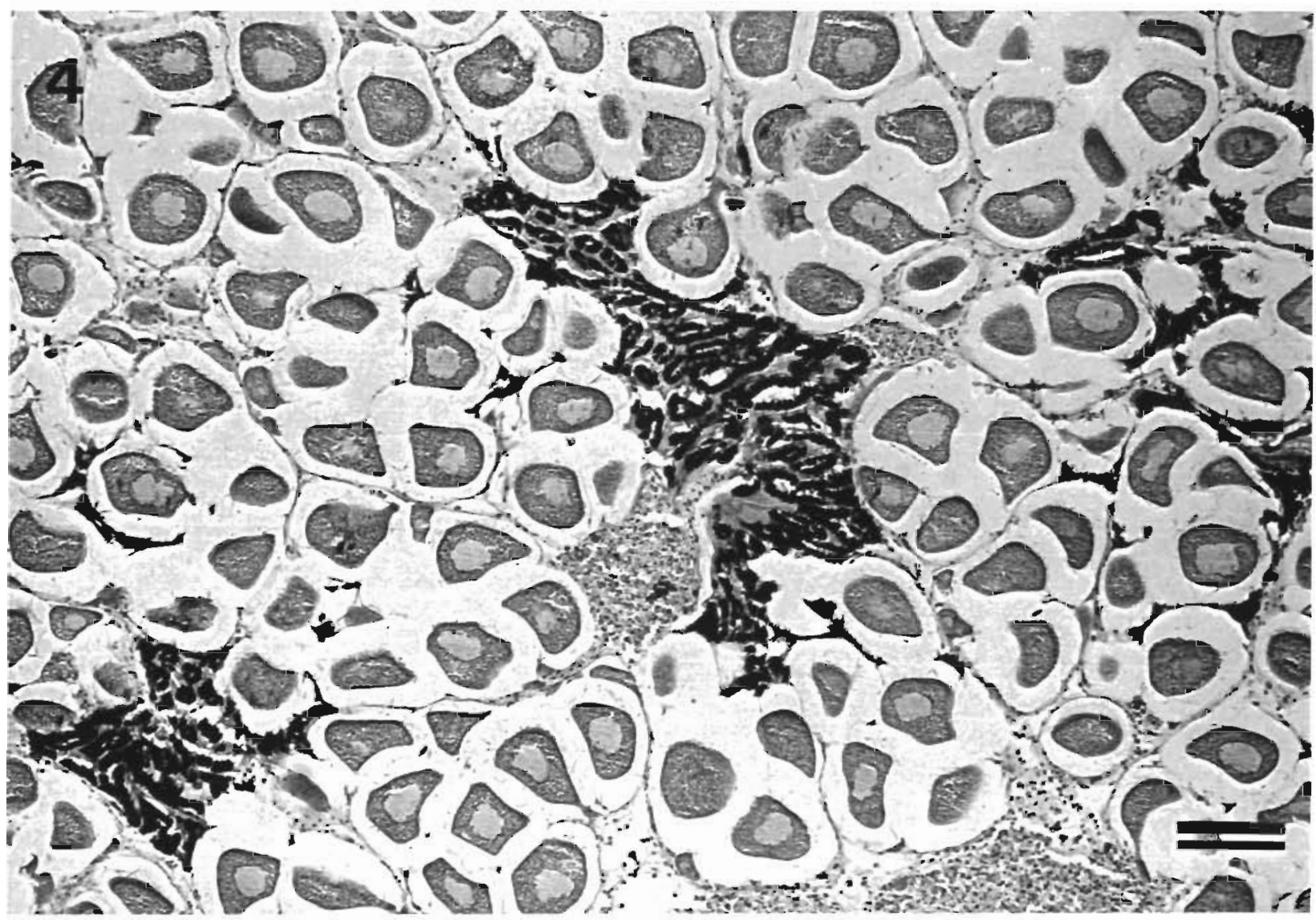

Fig. 4. Tridacna crocea. Normal hermaphrodite gonad with follicles of sperm and ova. H\&E; bar $=100 \mu m$ 
Pacific and the importance of the bucephalid described could be considerable if it is also present in other members of the Tridacnidae, either wild or cultured.

Acknowledgements. The senior author was funded by a Commonwealth Scholarship and Fellowship Plan scholarship and this work was undertaken as part of the Australian Centre for International Agricultural Research funded Internativ Giant Clam Mariculture Project. Orpheus Island Research Station and the School of Biological Sciences provided boats, facilities and equipment to collect and process the clams.

\section{LITERATURE CITED}

Bowers, E. A. (1969). Cercaria bucephalopsis haimeana (Lacaze-Duthiers 1854) (Digenea: Bucephalidae) in the cockle Cardium edule L. in South Wales. J. nat. Hist. 3: 409-422

Cheng, T C. (1967). Parasites of commercially important marine molluscs. Adv. mar. Biol. 5: 202-254

Cheng, T. C., Burton, R. W. (1965). Relationships between Bucephalus sp. and Crassostrea virginica: histopathology and sites of infection. Chesapeaks Sci. 6: 3-16

Cheng, T. C., Burton, R. W. (1966). Relationships between Bucephalus sp. and Crassostrea virginica: a histochemical study of some carbohydrates and carbohydrate complexes occurring in the host and parasite. Parasitology 56: $111-122$

Chun, S. K. (1974). Histopathology and localities infected by the Bucephalus sp. in oysters on the southern coast of Korea. Publ. Mar. Lab. Pusan Fish. Coll. 7: 77-86

Deltreil, J.-P., His, E. (1970). Concerning the presence of a trematode cercaria in Cardium edule in the Arcachon Basin. Rev. Trav. off. Pêches maritimes 34 (2): 225-232

Feng, S. Y., Canzonier, W. J. (1970). Humoral responses in the American oyster Crassostrea virginica infected with Bucephalus sp. and Minchinia nelsoni. In: A symposium on diseases of fishes and shellfishes. American Fisheries Society. Spec. Publ. No. 5: 497-510

Flook, J. M., Ubelaker, J. E. (1972). A survey of metazoan parasites in unionid bivalves of Garza-Little Elm Reservoir, Denton County, Texas. Texas J. Sci. 23 (3): 381-392

Huffman, J. E. (1985). Histopathology and histochemical effects of larval trematodes in Goniobus virginica (Gastropoda: Pleuroceridae). Veliger 27 (3): 273-281

Johnston, B. R., Halton, D. W., Moore, M. N. (1982). Bucephaloides gracilescens: a quantitative study of the lysosomal cellular stress response induced by the sporocysts and developing cercariae within the white furrow shell, Abra alba. Z. ParasitKde 67 (1): 31-36

Koubek, P. (1977). The discovery of the trematode Aspidogaster conchicola new record and the cercaria of Bucephalus polymorphus in our mussels. Folia Fac. Sci. Nat. Univ. Purkynianae Brun. Biol. 18 (9): 47-53

Lauckner, G. (1983). Diseases of Mollusca: Bivalvia - Agents: Trematoda. In: Kinne, O. (ed.) Diseases of marine animals,
Vol. II, Introduction, Bivalvia to Scaphopoda. Biologische Anstalt Helgoland, Hamburg, p. 632-762

Lauckner, G. (1986). Ecological effects of larval trematode infestations on littoral marine invertebrate popultions. In: Howell, M. J. (ed.) Proceedings of the 6th International Conference of Parisitology. Australian Academy of Science, Canberra, p. 391-398

Matthews, R. A. (1973). The life cycle of Bucephalus haimeanus Lacaze-Duthiers 1854, from Cardium edule. Parasitology 67 (3): 341-350

Millar, R. H. (1963). Oysters killed by trematode parasites. Nature, Lond. 197: 616

Mohan, J. M. (1978). Observations on the larval trematode Bucephalus sp. parasitic in the oyster Crassostrea madrasenis. J. Invertebr Pathol. 32 (3): 381-383

Munro, J. L., Heslinga, G. A. (1983). Prospects for the commercial cultivation of giant clams (Bivalvia: Tridancidae). Proc. Gulf Carrib. Fish. Inst. 35: 122-134

Pekkarinen, M. (1984). Trematode metacercariae in the extrapallial space of Macoma balthica (Bivalvia) in brackish water (southwestern Finland, Baltic Sea). Ann. Zool. Fennici 21: 473-480

Sakaguchi, S. (1964). Studies on a trematode parasite of the pearl oyster. II. Its effect on the oyster as first intermediate host. Bull. natn. Pearl Res. Lab. 9: 1161-1169

Sakaguchi, S. (1965). Studies on a trematode parasite of the pearl oyster (Pinctada martensii). $V$ Development of its cercaria in the first intermediate host. Bull. natn. Pearl Res. Lab. 10: 1244-1253

Sanders, M. J. (1966). Parasitic castration of the scallop Pecten alba (Tate) by a bucephalid trematode. Nature, Lond. 212: 307

Sanders, M. J., Lester, R. J. G. (1981). Further observations on a bucephalid trematode infection in scallops (Pecten alba) in Port Phillip Bay, Victoria. Aust. J. mar Freshwat. Res. 32: $475-478$

Stadnichenko, A. P. (1974). The infection of Unio pictorum and Anodonta piscinalis (Mollusca: Lammellibranchia) with parthenites of Bucephalus polymorphus trematodes and the effect of the parasites of the host organism. Parazitologiya 8 (5): 420-425

Stunkard, H. W (1976). The life cycles intermediate hosts and larval stages of Rhipidocotyle transversale and Rhipidocotyle lintoni life cycles and systematics of bucephalid trematodes. Biol. Bull, mar biol. Lab., Woods Hole 150 (2): 294-317

Tripp, M. R. (1973). Hermaphroditism in Bucephalus infected oysters. J. Invertbr. Pathol. 21 (3): 321-322

Turner, H. M. (1985). Parasites of eastern oysters from subtidal reefs in a Louisiana USA estuary with a note on their use as indicators of water quality. Estuaries 8 (3): 323-325

Umiji, S., Lunetta, J. E., Leonel, R. M. V. (1976). Infestation of the mussel Perna perna by digenetic trematodes of the bucephalidae family genus Bucephalus. An. Acad. Bras. Cienc. 47 (Suppl.): 115-117

Winsor, L. (1984). Manual of basic zoological microtechniques for light microscopy. School of Biological Sciences, James Cook University of North Queensland, Townsville 